\title{
The Significance of Transfer in the Process of English- Arabic Translation across Cultural Perspectives
}

\author{
Dr. Khalid Rokan Mansoor
}

Al-Turath University, Iraq

Received: 01 Jun 2021; Received in revised form: 25 Jun 2021; Accepted: 04 Jul 2021; Available online: 12 Jul 2021 (C2021 The Author(s). Published by Infogain Publication. This is an open access article under the CC BY license (https://creativecommons.org/licenses/by/4.0/).

\begin{abstract}
This paper discusses the culture-bound between Arabic and English and concentrates on the critical role of the cultural and linguistic system. The relationship between language, culture and translation is also discussed. Language predominately creates complicated dilemmas for translators and trainees of a second language, but the pivotal dilemmas, according to many theorists and scholars, materialize with cultural differences. Translation problems are represented by the differences between the source and target linguistic aspects and cultural areas. The theorists' preoccupations regarding the translation theory have included burgeoning cultural discussions in the translation study. The researchers have realized the necessity to research behind the boundaries of linguistic translation studies and discuss cultural approaches.
\end{abstract}

Keywords_Language, culture, English language, Arabic language and translation.

\section{INTRODUCTION}

In earlier works regarding translation theory, theorists and anthropologists have been involved in the definition of culture and language. Their relationship depended on the studies of different communities in which shifts and variations in language use are related to cultural components. Translation problems are presented from the difference between the source and target linguistic aspects and cultural areas. The translation is a communication way between human beings, and they use language as the most powerful method of communication, and language is controlled by cultures of nations, habits, conventionalism and beliefs. For instance, McGuire (1980) has asserted that "language is the heart with the body of culture, and it is the interaction between the two that results in the continuation of life" (p.22).

Translation researchers, such as Nida (1964), McGuire (1980), Newmark (1981), Hatim (1997), among others, have presented that there is an interlock and powerful relationship between culture and translation. In his efforts to clarify the intended role of translator and the translation as a theory, Nida (1964) has shown the cultural elements by defining that "the role of the translator is to facilitate the transfer of the message, meaning, and cultural elements from one language into another and create an equivalent response to the receivers" (p.13). Furthermore, Newmark (1988, p.22) foreign cultural elements consist of socialcultural, ecological, material and social traditions: religious, artistic, political, habits and gestures. Cultural elements can be presented in phrasal verbs, collocations, proverbs, and figures of speech.

\section{DEFINITION OF CULTURE}

Culture is the features and comprehension of a specific group of people, stated by everything from language, religion, beliefs, social habits, customs and arts. The concept of culture comes from a French word, which is initially derived from the Latin "colere", which refers to nature, earth and growth. Culture has been defined from different angles and discussed by many researchers. Tylor Richards (1957) has referred to the classical definition of culture as "culture or civilization taken in its wide ethnographic sense, is that complex whole which includes knowledge, beliefs, art, morals, law, customs, any other 
capabilities and habits acquired by man as a member of society." (p.16). Tylor has concentrated in his study of culture on complexity rather than wholeness.

Bindford (1968) has asserted that culture is an adaptive method that affirms that "culture is all those means whose forms are not under direct genetic control which serve to adjust individuals and groups within their ecological communities." (p.323). Another theorist has defined the concept of culture according to the whole way of life, whereas Hall (1982) has stated that "culture is not practice; nor it is simply the descriptive sum of the mores and folkways of societies-as it tended to become in certain kinds of anthropology." (p.22).

The above definitions of culture have given the same significance. Each scholar looks at the concept of culture as the situation, including human behaviours, social habits, customs, traditional morals, etc. Furthermore, Huxley (1955) has stated that culture is "the application by which anthropologists denote this central subject of their science" (p.10).

\section{THE ROLE AND RELATIONSHIP BETWEEN CULTURE AND LANGUAGE IN TRANSLATION}

Relationships between culture and language can be carried out through translation. Through translation processes, human beings are introduced to different languages and cultures. Therefore, the translator should understand the critical relationship between culture and language to shift the most acceptable equivalent since translation has played a vital role in the relationship between two cultures. Meanwhile, Delisle (1988) has clarified the relationship between culture and language in translation as "what truly distinguishes translation is that it takes place in the context of the relationship between two cultures, two words of thought and perception" (p.74).

Culture and language are distinctly the two controlling conceptions that make translation complex and pivotal. Each text has its characteristics, and the language system has its comprehensive characteristics, which refer to the context of culture. Perfectly, language is partially represented in the text, while culture represented through its situation. On the other hand, Newmark (1981) has pointed out that there is a cultural value in translation. The cultural concept in translation refers to a critical situation to have a successful shift from source and target language.

Furthermore, Nida and Taber (1974) assert cultural translation as "A translation in which the content of the message is changed to conform to the receptor culture in some way, or in which information introduced which is not linguistically implicit in original" (p.199). The potential role of the translator in transferring the cultural expressions in the target language has been stated by Newmark (1991), who argues that "the only problem is the degree to which the cultural expression is to be explained in translation, which may range from not at all, through a few hints to a full explanation in terms of functional or even TL cultural equivalent" (p.74). In contrast, Larson (1984) argues that a translator translates culture and not language. He has indicated that the significance of culture in translation as "Language is a part of the culture and, therefore, translation from one language to another cannot be done adequately without a knowledge of the two cultures as well as the two languages adequately without a knowledge of the two cultures as well as the two languages structures" (p.431). Furthermore, Huxley (1955) has stated that culture is "the application by which anthropologists denote this central subject of their science" (p.10).

Additionally, insufficient understanding may emerge from a lack of comprehension of the target culture and raises flawed equivalence between the source and target texts. There is an evident dissimilarity in cultural mores, traditions and beliefs between Arab and Western cultures. Bassentt and Trivedi (1999) have stated that translation is a cultural gesture related to "a highly manipulative activity that involves all kinds of stages in the process of transfer across linguistic and cultural boundaries" (p.2). For instance, when a translator/or translates from language/culture A to language/culture $\mathrm{B}$, she/or he is restricted by how they look at the other or vice versa and their tendency from their experiences about that language and culture.

\section{THE CHALLENGE OF CULTURE IN TRANSLATION}

One of the most complicated dilemmas in translation from English and Arabic results from the cultural variations between the source and target language. There are considerable differences in cultural materials such as beliefs, mores, politics, geography, climates, etc., between English and Arabic. The challenges will be less complicated in translation when the cultures are identical and will have the exact equivalence for the different cultural features. Readers and translators should be aware of their cultural environments and environments they are familiar with. Particular norms and mores of the Arabic culture could produce obstacles to all kinds of translation, especially religious and literary.

Nida (1964) has indicated that "where the linguistic and cultural distance between source and receptor codes are 
least, one should expect to encounter the least number of serious problems" (p.160). Consequently, if cultures are not systematically related, culture gaps will exist, and more changes and amendments are needed. Arabic is related to a specific culture and social mores entirely different from those related to other languages. As mentioned above, the Arabic culture is a constant conservative, and any irresponsible behaviours that come from an open or free society of particular culture are forbidden. The Arabic communities consist of restricted tribes, and the sense of pride in such tribal configuration is exceptionally high. On the other hand, most western cultures are self-reliant and accepted new traditions. Consequently, translators and readers meet a real difficulty in shifting cultural materials that are opposed to cultural, tribal mores of Arabic communities.

\section{CULTURAL EQUIVALENCE}

Since the era of translation theory started, and the debates of researchers have emerged in the translation process, cultural equivalence was a problematic issue in the research of scholars. The theorists' preoccupations regarding the translation theory have included burgeoning cultural discussions in the translation study. The researchers have realized the necessity to research behind the boundaries of linguistic translation studies and discuss cultural approaches. Language is the communicative system of humankind and renders perspectives, ideas and thoughts from one language into another and takes the cultural and linguistic aspects into account. Language is not only a group of sounds, words, sentences and structures. Many theorists, such as Anderson (2003); Buchowski (1996); Mona Baker (1996); Newmark (2006); Larson (1984); Fraghal (1995), have proven that cultural equivalence is one of the most problematic issues in the translation process. The translator has to deal with comprehensive elements of content, context, pragmatics, stylistics, semantics and syntax, not only with the equivalence of the meaning.

\section{CULTURAL ROLE IN TRANSLATION}

One of the controversial issues is that any translation process cannot be accepted unless the translators have compromised between the source and target language culture and take into account the environments of each of them separately. Theorists of translation, such as Nida (1964), Newmark (1988), Mason and Hatim (1997), among others, have indicated that there is a steady and branched relationship between translation and culture.
Moreover, language has produced challenging problems for translators and readers, but the distinguished dilemma, as stated by many theorists, happens because of cultural differences. The cultural aspect in translation is the most significant feature for an effective and acceptable translation. Cultural translation has occupied the most crucial role in linguistic layers and the translation process. If the translator is unaware of the cultural background of the source language, then she/or he will meet with awkwardness rendering the perfect meaning of the cultural materials that have been mentioned in the original text. The translator should not ignore the cultural aspect within the course of evaluation and translating the source text, and the translated version cannot be acceptable and effective unless it is in accordance with the linguistic and cultural aspects of the source text. On the other hand, the translation of English and Arabic consists of numerous confusions and hardness related to the system of two languages and the cultural aspect. Both languages belong to different linguistic families. Arabic is considered a Semitic language, while English is considered historically a Germanic language.

\section{INTRICATE AREAS IN CULTURAL TRANSLATION}

Cultural areas have become one of the argumentative issues in the translation process. Therefore, many scholars have had different perspectives about these cultural areas. Newmark (1988) asserts that culture is cognitive and pedagogical for a translator. However, it is the manner of life and its displays that are mysterious to societies that use language as its meaning. The most evident issue for the translation process is that cultural differences are considered one of the obstacles for translators in conveying the intended meaning from one culture to another, because languages differ in form and meaning. Languages are firmed in cultures that have various requirements, necessities and needs.

For instance, Nida (1964) points out that the cultural area is one of the essential aspects and has a vital role in language analysis and translation process. Therefore, he makes a distinction between five types of cultural aspects and discusses them in detail: (1) ecology, (2) material cultural, (3) social-cultural,(4) religious-cultural and (5) linguistic-cultural (p.91).

In environmental science, however, or ecology, Nida indicates that this kind includes atmosphere, fauna, flora, plants and humankind. According to the cases and situations of that area, these factors are entirely different from one area to another and produce various manners and thoughts. 
Material culture includes factors related to living conditions, such as foodstuff, connections, liveries, and life necessities.

Social Culture is considered one of the aspects of culture that relates to conventionalism, traditions, social relations, habits, life routine, behaviours etc.

Religious Culture relates to the incontrovertibleness. This cultural knowledge includes religious conduct and norms.

Linguistic Culture, this type of culture knowledge, deals with semantics, stylistics, syntax, phonology, morphology, etc. The differences in any language's nature and linguistic system lead to contrastive and complicated meanings and structures.

\section{CONCLUSION}

It has been concluded that this paper has shed light on critical areas of culture related to English/Arabic translation, particularly the role of culture in translation and the relationship between language and culture in the translation process. This paper includes an attempt to discuss the problems of culture and equivalence. It has indicated that translation difficulties of culture and equivalence are entirely overlapped. Different methods are used to overcome these problems to bridge cultural and linguistic differences between source and target texts.

In this paper, translation of culture from Arabic into English or vice versa could be related to linguistic and cultural origins. It is indispensable and substantial for the translator to be aware of both source and target language system and culture. Cultural difficulties of any given text force the translator to use cultural equivalent to make the text quite understandable to the reader and his culture. An essential study lying behind writing the current paper is to give help for novice of translation and trainees of English departments in Arabic countries. Moreover. It encourages practitioners and postgraduate of translation departments to create an idea that establishes a strong comprehension between translation theories and the importance of culture among communities.

\section{REFERENCES}

[1] Bassnett, S., \& Trivedi, H. (eds.) (1999). Post-Colonial Translation: Theory and Practice. London: Psychology Press.

[2] Bassnett, S. (1980). Translation Studies. London: Methuen.

[3] Bindford, L.R. (1968). Pot-Pleistocene Adaptation, in Binford, L.R.(ed), New perspective in Archeology. Chicago: Aldine Pop. Co, PP.313-341.
[4] Dejica, D. and M. Cernicova (eds.) Professional Communication and Translation Studies, 9/2017, Timisoara: Editura Politehnica.

[5] Delisle, J. (1988). Translation: An interpretive approach. University of Ottawa Press. Canada.

[6] Hall, S. (1981). Cultural studies: Two Paradigms, in Bannett, T.et al. (eds), Cultural, Ideology and Social Process: A Reader. Batsford Academic and Educational Ltd.

[7] Hatim, B \& Mason, I.(1990). Discourse and Translator. London: Longman.

[8] Hatim, B. (1997) Communication across cultures: translation theory and contrastive text linguistics. University of Exeter Press. UK.

[9] Hatim, B. \& Mason, I. (1997). The translator as a communicator. Routledge. UK.

[10] Huxley, J.S. (1955). Evaluation, Cultural and Biological. In Thomas, W.L.(ed), Wenner-Gren Yearbook, Vo. I. New York: Wenner-Gren Foundation for Anthropological Research.

[11] Larson, M. L. (1984). Meaning-Based Translation: A Guide to Cross-Language Equivalence. Lanham: University Press of American.

[12] Mansoor, K. (2017). The investigating semantic and syntactic equivalence in the translation process. Politechnical University Press of Timisoara. ISBN978-60635-0176-0.

[13] Mansoor, k. (2020). The Importance of Language in the World of Translation, College of Basic Education- AlMustanssiriyah University,2020 September. P: ISSN18157467. EISSN: 2706-8536.

[14] Mansoor, K. (2018). Translation Across the Difficulties of Equivalence Concept. Scientific Bulletin of the Politehnica University of Timişoara Transactions on Modern LanguagesVol. 17, Issue 1 / 2018.

[15] Mansoor, K. (2017). The concept of metaphor in the English-Arabic translation, in Dejica, D. and M. Cernicova (eds.) Professional Communication and Translation Studies, 9/2017, Timisoara: Editura Politehnica.

[16] Newmark, P. (1981). Approaches to Translation. Oxford: Pergamon.

[17] Newmark, P. (1988). A Textbook of Translation. New York: Prentice-Hall.

[18] Newmark, P. (1991). About Translation. London: PrenticeHall Int.

[19] Nida, E. (1964). Toward a science of Translating with Special Reference to Principles and Procedures Involved in Bible Translating. Leid: E.J. Brill.

[20] Nida, E. (1964). Linguistics and ethnology in translation problems. In Language and culture and society. Dell, $\mathrm{H}$. (ed.). Harper and Row. UK.

[21] Richards, I, A.(1957). The Concept of Culture in Malinowski's Work, in Firth, R. (ed.) Man and Culture. London: Routledge and Kegan Paul. PP. 14-31. 